\title{
STRATEGY FOR THE IMPLEMENTATION OF CREDIT COOPERATION MANAGEMENT SYSTEM BASED ONLINE APPLICATION TO INCREASE THE INCOME OF COOPERATIVE AND MEMBERS
}

\author{
Agung Sudjatmoko ${ }^{1}$, Febrizal Rahmana ${ }^{2}$, Aini Farmania ${ }^{3}$ \\ Bina Nusantara University \\ 1agung.sudjatmoko@binus.ac.id, \\ ${ }^{2}$ febrizal.rahmana@binus.ac.id \\ 3aini.farmania@binus.edu
}

Received: October $2^{\text {th }}, 2019 /$ Accepted: October $29^{\text {th }}, 2019$

\begin{abstract}
The application of business management systems and cooperative organizations faces the challenges of the development of business dynamics due to the development of science and technology. The use of information technology in all business actors is a form of adaptation to anticipate business development that aims to increase competitiveness and win competition. Cooperative is a business that still has obstacles in optimizing the use of IT to manage businesses in providing services to members. Therefore, through the use of the cooperative organization's business identification methods, the analysis of the guidelines for the use of cooperative online systems, training and outreach, and evaluating the implementation of activities. In this case, the community service activities can provide results that have an impact on optimizing the online cooperative system in improving services and incomes of members and cooperatives.
\end{abstract}

Keywords: Credit Cooperative Busness, Cooperative Management System, the Online Cooperative Application, The Income of Cooperative and Members

\section{INTRODUCTION}

The growth in the number of cooperatives until 2017 amounted to 208,619 cooperatives, and as many as $56,229(26.95 \%)$ inactive cooperatives, or as many as $152,390(73.05 \%)$ active cooperatives. The data from the Indonesian Ministry of Cooperatives and UKM is interesting because Indonesia has the largest number of cooperatives in the world. The number of individual members of the cooperative is $26,661,594$, or $11 \%$ of the population of our country. National cooperative business performance based on data from the Indonesian Ministry of Cooperatives and UKM until 2017 shows that the cooperative's own capital is Rp. 89.2 trillion, with outside capital of Rp. 82.9 trillion, bringing the total capital of the cooperative to Rp. 172.2 trillion. The cooperative business volume has been collected until 2017 is Rp. 178.5 trillion, and the remaining operating income of Rp. 6.08 trillion.

Koperasi Credit Sehati Jakarta is one of the well-developed cooperatives. Until 2017 the cooperative has 13,331 members, assets of Rp. 92.5 billion, member savings of Rp. 18.8 billion, a term savings of Rp. 55.5 billion and provide loans to members as large as Rp. 75.7 billion. Sehati is a credit cooperative in Jakarta that has implemented an online management system. After implementing 
an online system using the front end which is about 2 years has shown good development in terms of business and organization. However, the use of online systems in the cooperative has not been running optimally.

These empirical facts show that cooperatives are present and contribute to the social economy of their members. Difficulties of members or the community will be easy access to funding, and difficult to be met by banks, so the presence of savings and credit cooperatives or credit cooperatives has become a solution for the community. Cooperatives that have great potential, but their existence is not optimal, because they still have many obstacles and obstacles. Cooperatives have not become a mainstream business actor that has productivity, innovation and creativity comparable to private or state business actors. Locally and nationally cooperatives have not yet provided an optimal contribution to economic development, but have provided various forms of welfare to their members. There are still many problems in the management of savings and credit sector cooperatives including:

1. Not yet optimal utilization of online systems in cooperatives as a means for business management

2. Participation of members using the online system is still low, including to utilize the existing transaction system in the online application (purchase or payment)

3. The potential of big businesses to increase the income of cooperatives and members by using an online system has not been used optimally

In the era of increasingly high business competition, changes in business strategy and business dynamics are accelerating due to the development of science and technology. Businesses must also make changes by adapting technology and science. Changes in business management, services to members and using technology become adaptive choices that must be made by business actors including cooperatives. Using a savings and loan business management application system is an option that provides ease of preparation of reporting and services to members. Armed with the ownership of mobile phones members can see the development and business conditions of cooperatives, as well as to transact with their cooperatives. Incidentally, in the cooperative movement there is an integrated savings and loan cooperative application system with reporting called CUSO Mobile. Credit Cooperative Sehati already uses the online application system. For this reason, community service is carried out under the title Application of Online Application-Based Cooperative Management System for Savings and Loans Management to Increase Cooperative and Members Income.

\section{LITERATURE REVIEW}

The existence of cooperatives is still with an image with a small, traditional, poor image, and has not been able to consolidate the economic, social and cultural aspects of its members. The economic potential opportunities of its members are left alone and there is no attempt to seriously work in the business field. If cooperatives can immediately make changes, it is not impossible that cooperatives will become hefty economic actors. However, if the cooperative's business potential is allowed, then in this era of change the cooperative will continue to be a micro and marginal business actor. In the perspective of savings and credit cooperatives or credit will be an institution that has a loan shark. Savings and credit cooperatives or members become the choice of members/people because of their flexibility to borrow money to meet their needs, not because they are proud to be members of a cooperative that is able to resolve the lack of funds for their business. The compulsion of members to borrow in these cooperatives is due to the nature of cooperative business services that are flexible, easy, straightforward, unsecured loan guarantees, and various advantages of cooperative services compared to other financial institutions.

Based on these conditions, then changes must be made by cooperatives, changes related to organizational and business governance. Cooperatives since their birth as a corporate legal entity must conduct metamorphosis as a professional, independent, strong business actor and be able to capture every business opportunity that exists. The industrial revolution 4.0 has fundamentally changed life expectancy and the way people work. The demand for change also has a broader scale, scope and 
complexity. Technological advances have been able to integrate the physical, economic, digital, psychological and biological worlds and affect all disciplines of economics, industry, business and government.

In this 4.0 industrial revolution era, these cooperatives must make changes through the following strategies: a) cooperatives build their competitive advantage by applying science, innovation and technology and strengthening the social and economic consolidation of members. So that cooperatives become the strength of the captive market and competitive strategy in close economic view of and for members, b) cooperatives build modern management and e-smart coop by utilizing digital technology in the management of organizations and businesses. This system guarantees accountability and transparency in cooperatives which increases members' trust in cooperatives, because cooperatives are trusted organizations, c) increases the capacity of management, supervisors, management staff and members to build strong business synergies and provide appropriate compensation for guaranteeing the lives of cooperative actors, so that it will increase full responsibility for building a cooperative business without moral hazard in the cooperative body.

The philosophy of change in the era of the industrial revolution 4.0 is not the big or the strong, but who is agile and quick to make changes will become big and strong. The emergence of Alibaba, Gojek, Grab, RBnB, Tokopedia, Amazon, Traveloka and others has shown that those who change rapidly and are able to utilize technology are those who are able to master business resources without owning assets. They only master technology, provide application systems, utilize artificial intelligence (artificial intelligence), they are able to build business empires throughout the world. At this time IT, data and information become expensive commodities, those who master data and information will find new businesses that will continue to grow.

Based on the above problems, a change in online-based cooperative management that can build members' trust, as well as being able to increase cooperative income through fee-based income and members through payment and purchase services is urgently needed. To optimize the online savings and loan application management system and its use, guidelines are needed as an output of this activity, including increasing the capacity of online governance training in cooperatives.

\section{RESEARCH METHOD}

The method of implementing activities on the modernization of online-based savings and loan cooperative management is a series of activities that illustrate the steps towards implementing good management and optimal service to members. The flow of the implementation of these activities can be seen in the figure below: 


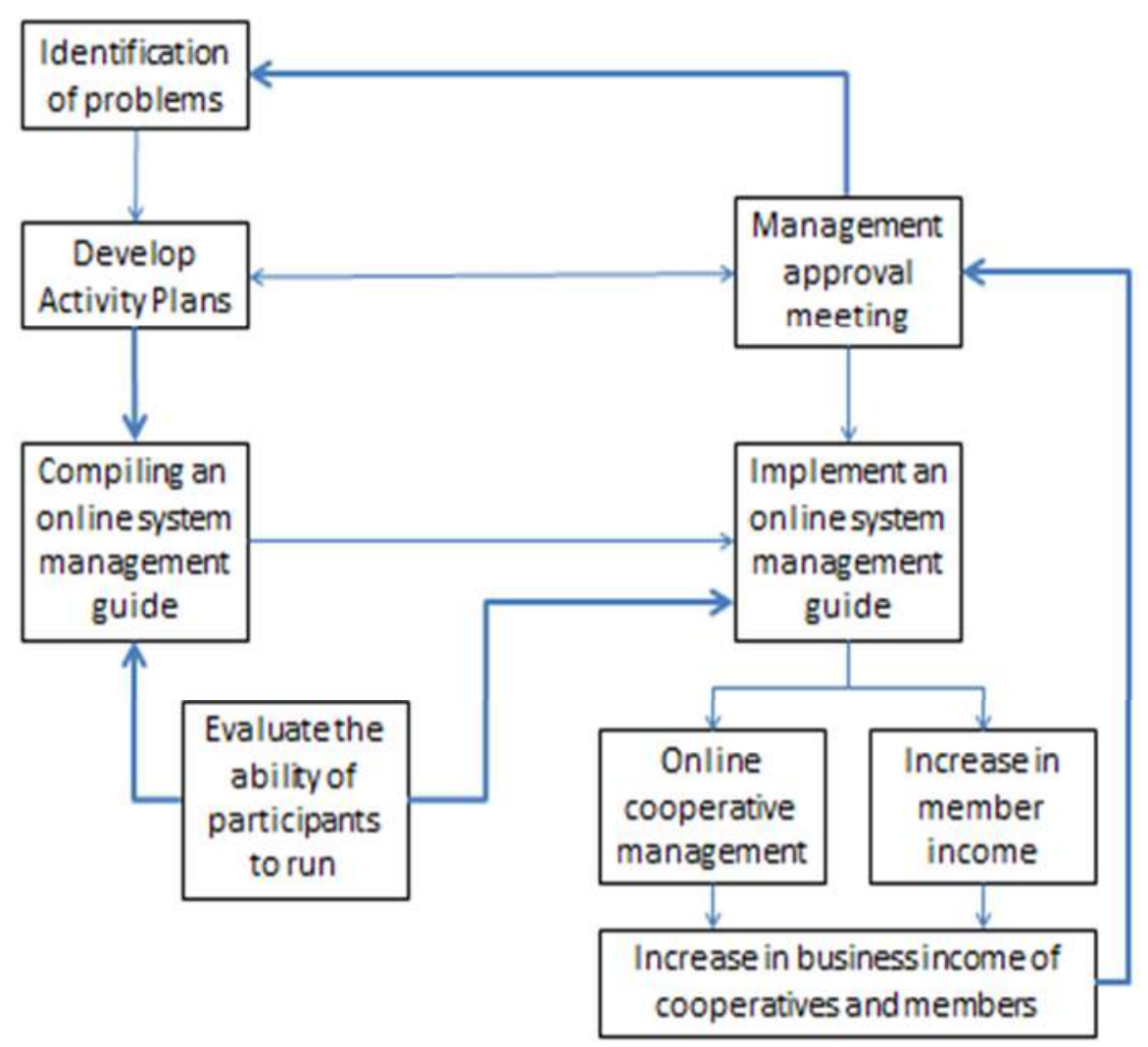

Picture 1: The flow of PKM activities

The description of the steps for carrying out the activity as in the picture above is as follows:

1. Identification of the cooperative where the PKM activities are as partners

2. Conducting communication and socialization about the online system at the time of drafting the program plan for optimizing the use of the online system for business and organizational development in cooperatives

3. Compile improvements to a short and easy guide to implementing online systems and optimizing the use of applications in cooperatives and members

4. Provide input in the form of perfecting the online system that is applied to be more optimal and better

5. Conduct training on the optimization of utilization optimization for management, members and employees

\section{DISCUSSION}

Identification of the place of service is done because of the various limitations that exist. Determine the choice that the cooperative that is a partner in accordance with the criteria is the Credit Cooperative Sehati in Pasar Minggu, South Jakarta. The criteria for cooperatives that become partners are a) have implemented an online system, b) implement cooperative management in accordance with the principles of cooperatives, c) have large members and d) governance of the cooperative works well. From the identification results of the Sehati Credit Cooperative, it can be concluded that the identification results are as follows: 
Table 1. Identification Results of Cooperative Partners

\begin{tabular}{|c|l|r|}
\hline No & \multicolumn{1}{|c|}{ Description } & \multicolumn{1}{|c|}{ Kopdit Sehati } \\
\hline 1 & Yearly established & 22 Agustus 1987 \\
\hline 2 & Legal entity & 17 Mei 1994 \\
\hline 3 & The number of members & 13.355 \\
\hline 4 & Assets & 92.258 .912 .823 \\
\hline 5 & Business volume & 76.244 .095 .800 \\
\hline 6 & Business volume & 18.924 .926 .912 \\
\hline 7 & Time Deposits (Deposits) & 55.404 .326 .123 \\
\hline 8 & Loan distribution & 76.244 .095 .800 \\
\hline 9 & Number of branches & 6 \\
\hline 10 & Number of group members & 24 \\
\hline 11 & Number of employees & ready \\
\hline 12 & Online systemSitem online & \\
\hline
\end{tabular}

Data: June 2019 Kopdit Sehati, Jakarta

Based on the above considerations, PKM conducts its service activities at the Sehati Credit Cooperative after seeing the results of identification considerations as above. Credit Cooperative Sehati has been using an online system, while the renewal of the use of the cuso mobile 2.0 online system has only been done for 1.5 years. For this reason, the concentration of community service activities is carried out on Sehati Credit Unit so that there will be a lot of various activities. Choices on Sehati Kopdit is a choice that is able to give an idea, how the online system has been running and has a big impact in the morning of membership growth and cooperative business development. Koperasi Credit Sehati who has used an online management system and has an apps store on a mobile phone (HP) that can be downloaded and used by members.

Prepare improvements to supporting guidelines, management systems on line at the cooperative. The improvement of various practical guidelines that will be used to conduct socialization to members of the cooperative is carried out with community service partner institutions, namely PT Indonesia Payment Incorporated (Pay.Inc) as a provider of online applications for cooperatives. As for the various guidelines that were reviewed and analyzed by the Team and made improvements to the guidelines / guidelines for using the online application system that has been prepared by the Team are as follows:

a) The cuso mobile practical guide, the improvements made by the Team are as follows:

\begin{tabular}{|l|l|l|l|}
\hline No & \multicolumn{1}{|c|}{ Previous } & \multicolumn{1}{c|}{ Completion } & \multicolumn{1}{c|}{ Results / Impact } \\
\hline 1 & $\begin{array}{l}\text { There are no key benefits to } \\
\text { using cuso mobile }\end{array}$ & $\begin{array}{l}\text { Plus information on } \\
\text { economic benefits for } \\
\text { members and cooperatives }\end{array}$ & $\begin{array}{l}\text { Increase member } \\
\text { understanding and the } \\
\text { importance of using } \\
\text { CUSO Mobile e }\end{array}$ \\
\hline 2 & $\begin{array}{l}\text { There is no flow chart for } \\
\text { downloading and using the } \\
\text { application }\end{array}$ & $\begin{array}{l}\text { Coupled with a flow chart for } \\
\text { using the cuso mobile } \\
\text { application }\end{array}$ & $\begin{array}{l}\text { Easy for members to } \\
\text { understand }\end{array}$ \\
\hline
\end{tabular}

b) Guide on how to activate cuso mobile, the improvements made by the Team are as follows:

\begin{tabular}{|c|l|l|l|}
\hline No & \multicolumn{1}{|c|}{ Previous } & \multicolumn{1}{c|}{ Completion } & \multicolumn{1}{c|}{ Results / Impact } \\
\hline 1 & $\begin{array}{l}\text { Activation that was } \\
\text { originally ID card identity } \\
\text { verification etc. first can } \\
\text { then enter the app store } \\
\text { display then can transact } \\
\text { with cuso mobile }\end{array}$ & $\begin{array}{l}\text { Reversed when kativasi has } \\
\text { appeared in the app store, } \\
\text { then enter the identity of the } \\
\text { ID card etc. to make } \\
\text { transactions with cuso } \\
\text { mobile }\end{array}$ & $\begin{array}{l}\text { ncrease } \\
\text { confidence }\end{array}$ \\
\hline 2 & $\begin{array}{l}\text { Initially there was no photo } \\
\text { of the participant's self- }\end{array}$ & $\begin{array}{l}\text { Coupled with the } \\
\text { participant's self-portrait }\end{array}$ & $\begin{array}{l}\text { Certainty of the owner of } \\
\text { the cell phone or account }\end{array}$ \\
\hline
\end{tabular}




\begin{tabular}{|c|l|l|l|}
\hline & portrait & using a cellphone & that is on cuso mobila \\
\hline 3 & $\begin{array}{l}\text { Not yet in cooperation with } \\
\text { Dukcapil for single } \\
\text { population data }\end{array}$ & $\begin{array}{l}\text { Cooperating with Dukcapil } \\
\text { to utilize single population } \\
\text { data }\end{array}$ & $\begin{array}{l}\text { Security integration with a } \\
\text { single population data that } \\
\text { belongs to the government }\end{array}$ \\
\hline
\end{tabular}

c) Guide to top up the cuso mobile balance, improvements made by the Team are as follows

\begin{tabular}{|c|l|l|l|}
\hline No & \multicolumn{1}{|c|}{ Previous } & \multicolumn{1}{c|}{ Completion } & \multicolumn{1}{c|}{ Results / Impact } \\
\hline 1 & $\begin{array}{l}\text { Payment gateway } \\
\text { transactions are only for } \\
\text { purchasing pulses, data, } \\
\text { games, electricity tokens } \\
\text { and paying for electricity } \\
\text { and electricity }\end{array}$ & $\begin{array}{l}\text { The number of PDAMs was } \\
\text { expanded, the payment of BPJs } \\
\text { was open, and various other } \\
\text { payments were made, including } \\
\text { withdrawals and deposits } \\
\text { between cooperatives using } \\
\text { Cuso users and with modern } \\
\text { retail. }\end{array}$ & $\begin{array}{l}\text { Providing ease } \\
\text { member transactions }\end{array}$ \\
\hline 2 & $\begin{array}{l}\text { Top ups only use BNI and } \\
\text { BCA smoothly }\end{array}$ & $\begin{array}{l}\text { Cuso wallet top up wallet } \\
\text { cooperation was opened with } \\
\text { BRI, Mandiri and BTN }\end{array}$ & $\begin{array}{l}\text { Ease of user top-up } \\
\text { transactions }\end{array}$ \\
\hline
\end{tabular}

d) Guide to knowing your customer, the improvements made by the Team are as follows:

\begin{tabular}{|c|l|l|l|}
\hline No & \multicolumn{1}{|c|}{ Previous } & \multicolumn{1}{c|}{ Completion } & \multicolumn{1}{c|}{ Results / Impact } \\
\hline 1 & $\begin{array}{l}\text { Initially only knew the need } \\
\text { to use cuso for what } \\
\text { purposes, and the number } \\
\text { of transactions }\end{array}$ & $\begin{array}{l}\text { Coupled with knowing the user's } \\
\text { age, time of use of the } \\
\text { application, usage analysis } \\
\text { securitization etc. }\end{array}$ & $\begin{array}{l}\text { Knowing the pattern } \\
\text { and application } \\
\text { development including } \\
\text { its securitization }\end{array}$ \\
\hline
\end{tabular}

In addition to these activities, materials needed are needed for socialization materials so that cooperative members can use this application system to increase: a) participation of cooperative members in conducting transactions with cooperative businesses, b) increase members' trust in cooperatives, c) build together economic empowerment of members and d) increase cooperative income with its members.

1. Training on socialization to improve the ability of cooperative managers and members.

Socialization training activities to increase the ability of cooperative managers for management, managers and members in using the cooperative management application system. Utilization of the application of technology application systems to increase revenue. As for the benchmarks for socialization of capacity building that will be used include the following:

a. Manager

1) Utilization of online technology for cooperative management

2) Online technology for business development

3) Technology and increasing the number of members as well as the income of cooperatives and members

b. Member

1) The usefulness of online technology for members

2) Increasing member participation in cooperatives through technology

3) Hunger members of cooperatives with online technology

2. Technical assistance to optimize the application of online systems in cooperatives

The form of activities carried out by the Team at this stage is to provide input to:

a. Development of applications to develop features or improve application systems to improve cooperative management systems

b. Cooperative management to further optimize the use of online applications for ease of members making transactions 
c. Members of the cooperative to increase participation and income using various features for the benefit of his personal business.

3. Development of cooperative organizations and businesses

After the application of the cooperative management online application system, it can be described the growth and development of cooperatives in the Sehati Credit Cooperative are as follows:

Matrix 1. Organizational and Business Development

\begin{tabular}{|c|l|r|r|c|}
\hline \multirow{2}{*}{ No } & \multicolumn{1}{|c|}{ Field } & \multicolumn{2}{|c|}{ State of the Cooperative } & Increase \\
\cline { 3 - 4 } & & 31082018 & 31082019 & $(\%)$ \\
\hline 1 & The number of members & 11.681 & 13.938 & 19,32 \\
\hline 2 & Business volume & 7.933 .379 .897 & 8.205 .876 .319 & 3,43 \\
\hline 3 & Members' principal deposits & 1.168 .100 .000 & 1.393 .600 .000 & 19,30 \\
\hline 4 & Mandatory savings for members & 10.599 .167 .000 & 12.493 .651 .000 & 17,87 \\
\hline 5 & Voluntary deposits for members & 5.086 .502 .358 & 5.792 .899 .642 & 13,89 \\
\hline 6 & Member savings / deposits & 53.530 .190 .253 & 56.809 .757 .071 & 6,13 \\
\hline 7 & Loans played to members & 65.077 .937 .100 & 78.290 .757 .250 & 20,30 \\
\hline
\end{tabular}

Data: Processed from primary data provided by the Sehati Kopdit management, 2019

Based on the data above shows that the growth and development of cooperatives after using an online system shows very good conditions. In general the development of cooperatives shows good development. The number of members experienced a growth of 19.32 percent. This gives the meaning that the community is interested in becoming members with various perceptions, because of the ease that is in the cooperative, the more widespread information that because of using technology, community trust grows because the cooperative is able to adapt technological developments, the transparency of cooperative management and many other considerations among the community.

The business aspect also shows a very good growth or development, with the addition of members and the growth of public trust, it will have an impact on growth in the cooperative business. whisper growth also gives a pretty good number as in matrix 6.3 above. Based on the data above, it can be concluded that the use of technology with an online system properly will provide growth and development of businesses and organizations for cooperatives. For this reason, there is no other choice for cooperatives to immediately make changes by adapting technology in business governance and their organizations.

In the aspect of application system utilization which is carried out in Sehati Kopdit by members even though it has experienced growth needs to be improved properly. From the primary data provided by the Sepati Kopdit Management in September 2019, from as many as 13,938 members, only 763 people downloaded the cooperative application, or 0.54 percent, indicating that it is still far from expectations. The impact of the number of members conducting transactions with the application was 2,849 transactions with a turnover of $\mathrm{Rp}$. $470.505,282$. This also shows that technology provides a change in the form of business turnover in a cooperative. The form of activities carried out by the Team at this stage was to provide input to:

a. Application developers to develop features or improve application systems to improve cooperative management systems. various suggestions that have been made by the PKM implementation team for application development include:

1) Add application features in the existing front end app especially to facilitate participant registration especially for activation. Changes to the activation procedure are made to be more concise than the previous process;

2) To make it easier for members to carry out transactions with their cooperatives, it is necessary to add a "member deposit" feature so that members can pay for various deposits, such as stock, daily deposits, or repay member loans to their cooperatives.

3) It is also recommended that all cooperatives that already use the cuso mobile application members can make withdrawal and deposit transactions in cooperatives that exist online, making it easier for members to carry out transactions wherever and whenever. (this suggestion cannot be done by application developers because it requires a system and regulation of cooperation between application user cooperatives and stronger than BI or OJK) 
4) It is also recommended that application developers can also collaborate with other business institutions such as Indomart or Alfamart to deposit and withdraw cash as well as to facilitate cooperatives in providing services to members because these business institutions have extensive networks and many financial institutions have cooperated with they provide services to the community. Many conveniences if the cuso mobile application used in cooperatives such as the Kopati Sehati if developed include:

a) Proximity of members to be able to withdraw and deposit to the cooperative,

b) Ease of service as part of the modern retail is open 24 hours,

c) Efficiency of membership services because there is no need to open a cooperative service branch, and

d) Cooperatives have been able to open themselves to collaboration with other businesses with sharing systems in the era of the industrial revolution

b. Cooperative management to further optimize the use of online applications for ease of members conducting transactions, the activities carried out by PKM Binus Team are: conducting discussions for the development of a more complete online system and providing convenience and security guarantees for the developed application system. This, according to the team, is very important because it is able to give members of the cooperative confidence in the ease, speed, transparency and security of the money saved by members in the cooperative. To give more meaning to the cooperative, the cooperative management must increase socialization with various interesting activities for members to download the application and use the application for purchasing and payment requirements. This will increase income for the cooperative by $10 \%$ of each member who transacts. In addition, members will also get a cash back of $10 \%$ for transactions of members who use the application for purchases or payments.

c. Members of the cooperative to increase participation and income using various features for the benefit of his personal business. Related to this, PKM Binus team motivated members that in the cooperative members were both owners and users of cooperative business services. Participation of members in cooperatives determines the size and progress of cooperatives, the more cooperative members that transact, the greater the business volume of the cooperative. For this reason, administrators need to make various agenda of activities that are able to attract and motivate members to use and make transactions with applications that are in the cooperative.

\section{CONCLUSION}

1. The implementation of community service activities gives a great meaning to our understanding that cooperatives as entrepreneurs must also adapt to the development of science and technology, including using information technology in particular. The focus of community service carried out is as follows:

a) Completion of guidelines for the utilization of online application systems in cooperatives so as to facilitate the use of both cooperatives and members

b) Socialization of the utilization of cooperative online application systems to management and members of the cooperative.

Cooperatives that use applications show growth and development in terms of organization and business. On the organizational side the following occurs:

a) increase in the number of members increased because of the convenience of the community to become members of the cooperative

b) the wider working area that can be reached by cooperatives because the application does not recognize the distance and time limits, and

c) the trust and confidence of members is built on their cooperative efforts that are increasingly advanced so as to foster the confidence, commitment and loyalty of members in the cooperative.

2. While on the business side, it gives an impact on the business side, showing a good development towards:

a. addition of principal, mandatory and special deposits 
b. the existence of other income in cooperatives, especially passive income for the incomemaking transactions conducted by members

c. increased participation of member transactions

d. increase the volume of cooperative businesses, and

e. qualitatively increase members 'confidence, members' pride in their cooperation, commitment and loyalty of members to the cooperative.

3. Development of various service features in cooperative application systems that are used that aim to provide additional facilities in accordance with the needs of members and the development of a growing business model. Models of cooperation with other businesses to attract and deposit, such as cooperation with modern retail or banks and even financial institutions both banks and non-banks can also be developed so that cooperatives will be able to become equal business actors in providing services to members. Many benefits and advantages with this business pattern, so that the adaptation of cooperatives using online management systems has a great impact on the trust of members, modernization of cooperative management, and the image of cooperatives as superior business actors and have competitiveness with other business actors.

\section{REFERENCES}

Ake Book, 1994,. Sven Nilai-Nilai Koperasi Dalam Era Globalisasi, Koperasi Jasa Audit Nasional, Jakarta

Astri Ocktora Sinaga; Kusumantoro, (2015), Kualitas Pelayanan, Kemampuan Manajerial Pengurus, Motivasi Anggota Dan Citra Koperasi Terhadap Kepuasan Anggota Koperasi, FE Unnes, Semarang.

Hadi Juwono, Handito, 2005,.“7n1” Business Competition Strategy, Bisnis Indonesia, Jakarta

Joewono, Handito (2017) The 5 Arrows of Neo Star up, Jakarta, PT Arrbey International, Jakarta

PICU, Majalah Gerakan Koperasi Kredit Indonesia, No. 49/Th 1, Edisi Mei-Juni 2019, Inkopdit, Jakarta

Ropke, J. (2003). Ekonomi Koperasi Teori dan Manajemen. (S. Djatnika, Penerj.) Jakarta: Salemba Empat.

Zulkarnain, Drs,. MM,. 2006, Kewirausahaan, Strategi Pemberdayaan Usaha Kecil, Menengah dan Penduduk Miskin, Adicitra Karya Nusa, Yogjakarta 